\title{
Morphophysiological aspects of young Calotropis procera plants submitted to different shading levels
}

Aspectos morfofisiológicos de plantas jovens de Calotropis procera submetidas a diferentes níveis de sombreamento

\section{J. E. S. Ribeiro ${ }^{1 *}$; F. R. A. Figueiredo²; E. S. Coêlho²; M. B. Albuquerque ${ }^{1}$}

${ }^{1}$ Laboratório de Ecologia Vegetal, Universidade Federal da Paraíba, 58397-000, Areia-Paraíba, Brasil

${ }^{2}$ Laboratório de Microbiologia Agrícola, Universidade Federal Rual do Semi-Árido, 59625-900, Mossoró-Rio Grande do Norte, Brasil

*j.everthon@hotmail.com

(Recebido em 30 de julho de 2019; aceito em 26 de novembro de 2019)

\begin{abstract}
The silk flower (Calotropis procera) is a plant found practically in the whole Northeast region of Brazil and can be used for several purposes. However, its morphophysiological characteristics may be influenced by the degree of brightness. This study aimed to evaluate the morphophysiological behavior of silk flower under different shading levels. The experiment was carried out in a greenhouse belonging to the Federal University of Paraíba, Areia, Paraíba, Brazil. The experimental design was completely randomized, with five treatments and eight repetitions. The treatments used were different shading levels: 0 (full sun), 30\%, 50\%, 70\% and $90 \%$ of shading. Growth characteristics, morphofunctional attributes, gas exchange and chlorophyll a fluorescence were evaluated. The data were submitted to analysis of variance by the F-test, and in cases of significance, a polynomial regression analysis was performed. The best result for the plant height was found at the shading level of $68.4 \%$. Gas exchange and chlorophyll a fluorescence variables presented higher values in the levels of higher light availability. Silk flower plants grow best under full sun conditions. Shading negatively affects the gas exchange and quantum efficiency of silk flower plants.
\end{abstract}

Keywords: silk flower, irradiance, photosynthesis.

A flor de seda (Calotropis procera) é uma planta encontrada praticamente em toda a região Nordeste, podendo ser utilizada para diversos fins. No entanto, suas características morfofisiológicas podem ser influenciadas dependendo do nível de luminosidade. Com o presente trabalho, objetivou-se avaliar o comportamento morfofisiológico da flor de seda sob diferentes níveis de sombreamento. O experimento foi conduzido em casa de vegetação pertencente à Universidade Federal da Paraíba, Areia, Paraíba, Brasil. O delineamento experimental foi inteiramente casualizado, com 5 tratamentos e 8 repetições. Os tratamentos utilizados foram compostos por diferentes níveis de sombreamento: 0\% (pleno sol), 30\%, 50\%, 70\% e 90\% de sombreamento. Para as análises, foram avaliadas características de crescimento, atributos morfofuncionais, trocas gasosas e fluorescência da clorofila $a$. Os dados foram submetidos à análise de variância pelo teste $\mathrm{F}$ e, em casos de significância, foi realizada uma análise de regressão polinomial. O melhor resultado para altura de plantas foi encontrado no nível de sombreamento de $68,4 \%$. As variáveis de trocas gasosas e fluorescência da clorofila a apresentaram valores superiores nos níveis de maior disponibilidade de luz. Sob as condições em que o experimento foi conduzido, as plantas de flores de seda se desenvolvem melhor em condições de pleno sol. Sombreamento influencia negativamente a fisiologia das plantas de flores de seda.

Palavras-chave: flor de seda, irradiância, fotossíntese.

\section{INTRODUCTION}

Silk flower [Calotropis procera (Ait.) R.Br. - Apocynaceae] is a spontaneous species very common in the Northeast region of Brazil. Several uses have been attributed to this species, such as the use in folk medicine in the treatment of ulcers, tumors, hemorrhoids and diseases of the spleen, liver and abdomen [1]; it can be used as a source of green fertilizer, especially in intercropped crops [2], as well as in animal supplementation [3], mainly in semi-arid regions.

Fluctuations in environmental factors such as irradiance, temperature and water availability can lead to reductions in plant vigor, leading to less growth and development [4]. Among these factors, irradiance is one of the most important, which directly influences the most varied physiological 
processes, regulating primary production and, consequently, acting significantly on plant growth [5].

Light is one of the most important ecological factors, being able to interfere significantly in all phases of plant development, as well as in the most varied physiological processes, occurring great diversity of plant responses to light energy [6]. In this regard, changes in brightness levels to which a given species is adapted may induce several physiological responses, such as variations in gas exchange and chlorophyll indices, altering its biochemical and anatomical characteristics [7].

Corroborating these statements, some works studying forest species show these differences between the levels of brightness in the development of plants, such in Cupania vernalis Cambess [8], Tapirira guianensis Alb. [9] and Bertholletia excelsa Blonp [10] plants. Given the above, studies that seek to know the growth, development and physiological behavior of plants under shading conditions are of great importance.

Therefore, the objective of this study was to evaluate the morphophysiological behavior of silk flower (Calotropis procera) under different shading levels.

\section{MATERIAL AND METHODS}

The experiment was carried out in a greenhouse of the Laboratory of Plant Ecology, Department of Plant Science and Environmental Sciences, Center of Agricultural Sciences, Federal University of Paraíba, Campus II, Areia, Paraíba, Brazil. The environment presented average temperature of $29.3{ }^{\circ} \mathrm{C}$ and relative humidity of $52.5 \%$, whose measurements were made using a portable digital thermo-hygrometer (Minipa, model MT-241A).

The seeds of silk flower were collected directly in different matrices plants in the municipality of Catolé do Rocha, Paraíba, Brazil. Before planting, the seeds were soaked in distilled water for a period of 12 hours, then sown in plastic pots with capacity for $5 \mathrm{dm}^{3}$, and in substrate formulated by organic soil and sand (3:1 v/v). The chemical analysis of this substrate was: $\mathrm{pH}: 4.7 ; \mathrm{P}: 109.81$ $\mathrm{mg} \mathrm{dm}{ }^{-3} ; \mathrm{K}^{+}: 216.02 \mathrm{mg} \mathrm{dm}^{-3} ; \mathrm{Na}^{+}: 0.48 \mathrm{cmol} \mathrm{dm}{ }^{-3} ; \mathrm{H}^{+}+\mathrm{Al}^{+3}: 6.11 \mathrm{cmol} \mathrm{dm}^{-3} ; \mathrm{Al}^{+3}: 0.05 \mathrm{cmol} \mathrm{dm}^{-}$ ${ }^{3} ; \mathrm{Ca}^{+2}: 4.20 \mathrm{cmol} \mathrm{dm}^{-3} ; \mathrm{Mg}^{+2}: 2.60 \mathrm{cmol} \mathrm{dm}^{-3}$; base sum: $7.83 \mathrm{cmol} \mathrm{dm}^{-3}$; cation exchange capacity: $13.94 \mathrm{cmol} \mathrm{dm}^{-3}$; and organic matter: $65.31 \mathrm{~g} \mathrm{dm}^{-3}$.

Three seeds/vessels were used and thinning was performed 10 days after emergency (DAE), selecting uniform individuals, with a mean height of $4 \mathrm{~cm}$. The plants were transferred to the different shading levels (treatments), and evaluations were initiated 30 DAE. The place of the experiment has high coverage and specific areas, so that the brightness was not influenced during the sunlight. During the experimental period, the irrigation of the plants occurred daily, the pots were weighed and rotated, maintaining the field capacity around $80 \%$.

The experimental design was completely randomized, with five treatments and eight repetitions, one plant in each. The treatments used were different shading levels: 0 (full sun), 30\%, 50\%, 70\% and $90 \%$ of shading.

Plant height $(\mathrm{PH}-\mathrm{cm})$ and stem diameter $(\mathrm{SD}-\mathrm{mm})$ were evaluated at 30 and $60 \mathrm{DAE}$. The plants were separated from the vases and the leaves, stems and roots were collected at 60 DAE. They were then stored in kraft paper and hot air circulation oven drying at $65{ }^{\circ} \mathrm{C}$ for 72 hours. Subsequently, the dry mass of the leaves (DMW), stems (DMS), roots (DMR) and total dry mass (TDM) were measured, and the results were expressed in $\mathrm{g} \mathrm{plant}^{-1}$.

The length of the main root $(\mathrm{cm})$ was determined by means of a millimeter ruler. The volume of the root system was obtained from the displacement of the water column in a graduated cylinder, the roots emerging in a known volume of water $(50 \mathrm{~mL})$. The root biomass partition was calculated according to Benincasa (1998) [11].

The Dickson quality index (DQI) was determined as a function of the total dry mass (TDM), dry mass ratio of the shoot with the dry mass of roots (DWSR) and the relation between of the plants height and stem diameter (RHS), according to the equation proposed by Dickson et al. (1960) [12]: $\mathrm{DQI}=[\mathrm{TDM} /(\mathrm{DWSR}+\mathrm{RHS})]$.

For the analyzes of gas exchange, it was measured at $60 \mathrm{DAE}$, the $\mathrm{CO}_{2}$ assimilation rate (A $\mu \mathrm{mol} \mathrm{CO} \mathrm{Cm}^{-2} \mathrm{~s}^{-1}$ ), stomatal conductance ( $\mathrm{gs}-\mathrm{mol} \mathrm{H}_{2} \mathrm{O} \mathrm{m}^{-2} \mathrm{~s}^{-1}$ ), transpiration $\left(\mathrm{E}-\mathrm{mmol} \mathrm{H}_{2} \mathrm{O} \mathrm{m}^{-2} \mathrm{~s}^{-}\right.$ ${ }^{1}$ ), internal $\mathrm{CO}_{2}$ concentration (iC $-\mu \mathrm{mol} \mathrm{CO}_{2} \mathrm{~mol}^{-1}$ ) and leaf temperature (Tleaf $-{ }^{\circ} \mathrm{C}$ ). Subsequently, from these data the water use efficiency $[\mathrm{WUE}=(\mathrm{A} / \mathrm{E})]\left[\left(\mu \mathrm{mol} \mathrm{CO} \mathrm{C}^{-2} \mathrm{~s}^{-1}\right) /(\mathrm{mmol}\right.$ 
$\left.\left.\mathrm{H}_{2} \mathrm{O} \mathrm{m}^{-2} \mathrm{~s}^{-1}\right)\right]$ and instantaneous carboxylation efficiency [iCE $\left.=(\mathrm{A} / \mathrm{Ci})\right]\left[\left(\mu \mathrm{mol} \mathrm{CO} \mathrm{CO}_{2} \mathrm{~m}^{-2} \mathrm{~s}^{-1}\right) /(\mu \mathrm{mol}\right.$ $\left.\left.\mathrm{CO}_{2} \mathrm{~mol}^{-1}\right)\right]$ were analyzed. The analyzes were performed on healthy and fully expanded leaves in the middle third of the plants in day with total conditions of solar luminosity, from 10 a.m. and 11 a.m. The analyzes were performed using a portable infrared gas analyzer (IRGA - LiCOR, model LI-6400XT).

Chlorophyll a fluorescence, initial fluorescence $\left(\mathrm{F}_{0}\right)$, maximum fluorescence $\left(\mathrm{F}_{\mathrm{m}}\right)$, variable fluorescence $\left(\mathrm{F}_{\mathrm{m}}-\mathrm{F}_{0}\right)$, maximum quantum yield of PSII $\left(\mathrm{F}_{\mathrm{v}} / \mathrm{F}_{\mathrm{m}}\right)$ and $\mathrm{F}_{\mathrm{v}} / \mathrm{F}_{0}$ ratio were evaluated at 60 DAE. For the measurements, healthy leaves were used in the medium height of the plants, being adapted to the dark by means of leaf-clips during a period of 30 minutes. A portable modulated fluorimeter (Sciences Inc.-model OS-30p, Hudson, USA) was used for the analysis.

Data were submitted to analysis of variance by the $F$ test, and in the cases of significance a polynomial regression analysis was performed, with the adjustment of the representative curves. Statistical analyzes were performed using SAS ${ }^{\circledR}[13]$.

\section{RESULTS AND DISCUSSION}

The plant height $(\mathrm{PH})$ was higher at $60 \mathrm{DAE}$, being found higher values at the shading level of $68.4 \%$, providing plants with an average height of $19.7 \mathrm{~cm}$ (Figure 1A). The stem diameter (SD), the increase in the shading levels caused linear reductions for this variable at both 30 and $60 \mathrm{DAE}$ (Figure 1A). It is possible to affirm that the silk flower presents higher height and smaller stem diameter in unfavorable light conditions, being a consequence of shading, inducing the elongation of the stem by the auxin flow (etiolation) [14].
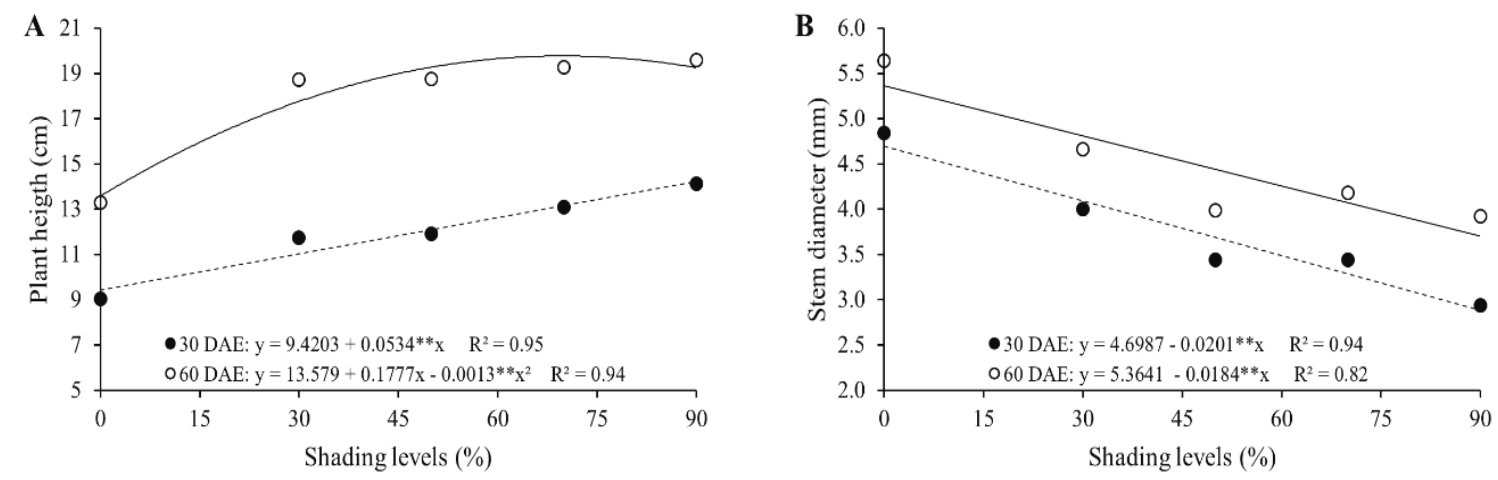

Figure 1: Plant height (A) and stem diameter (B) in plants of silk flower (Calotropis procera) at 30 and 60 days after emergency (DAE) as a function of shading levels.

The dry masses of leaves (DML), stem (DMS), root (DMR) and total (TDM) have reduced linearly as a function of the increase in the shading levels, decreases in the order of 64.6; 66.3; 95.6 and $70.2 \%$, respectively (Figure 2A, B, C and D). The lower production of biomass under shading conditions is an indication that the reduction in the amount of incident light impaired the production of photoassimilates, due to a lower absorption of photons, causing lower performance of the photosynthetic apparatus [15]. 

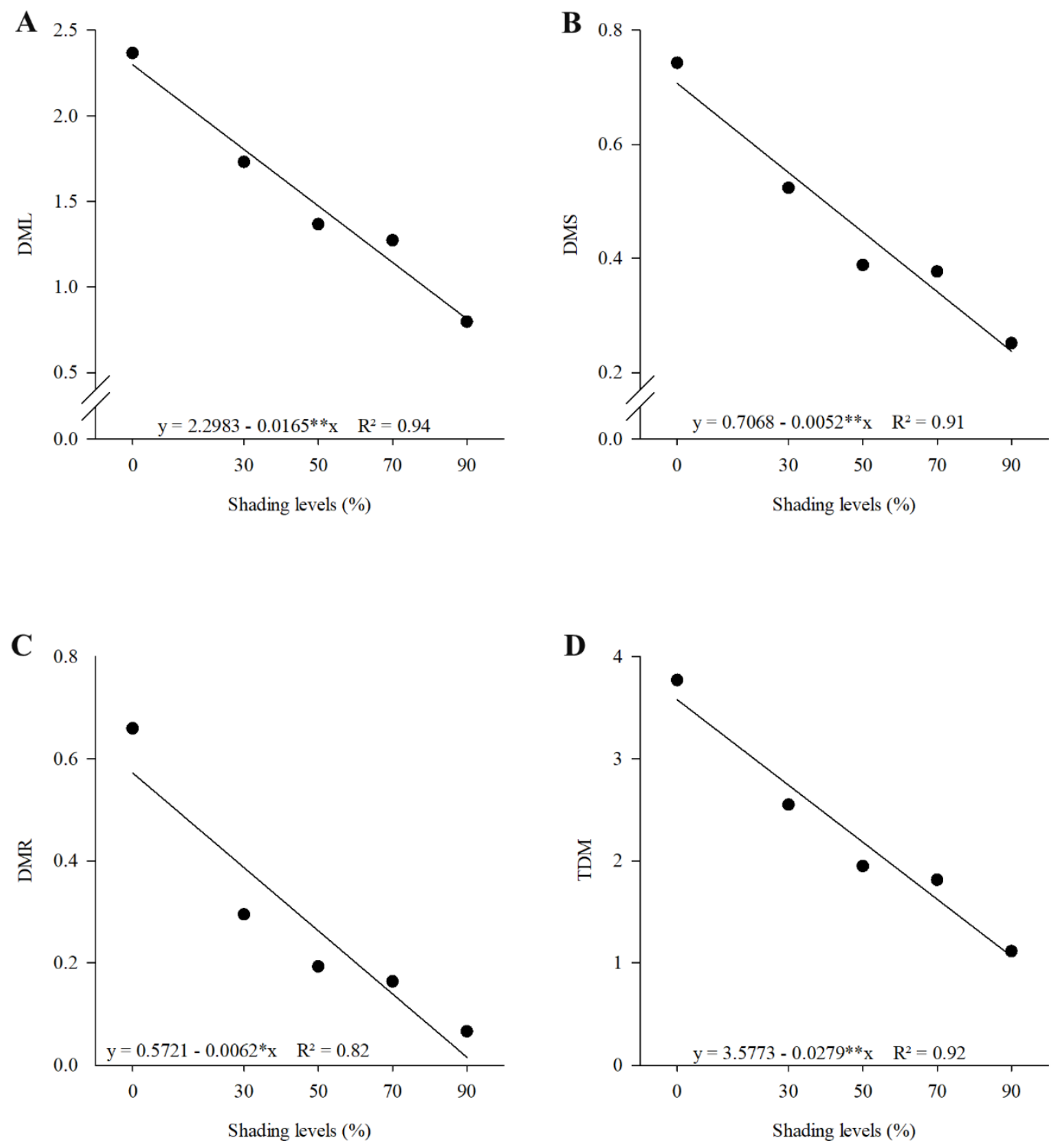

Figure 2: Dry mass of leaves (A), stems (B), roots $(C)$ and total (D) in plants of silk flower (Calotropis procera) as a function of shading levels.

The length, volume and partition of root biomass, the values were adjusted to a decreasing linear effect, showing reductions of 31.2; 95.1 and $65.9 \%$ in shading of $90 \%$ when compared to the control treatment (full sun) (Figures 3A, B and C). The best performance of $C$. procera in sunny conditions corroborates the indication of this species as a heliophylic plant, because it is native to regions where there are high temperatures and brightness (Tropical Africa and India) [16].

Evaluating seedling quality through the Dickson Quality Index (DQI), the treatment in full sun $(0 \%)$ was the one that presented the best result $(0.51)$, and in the $82.2 \%$ shading was registered the biggest decrease $(86.2 \%)$ (Figure 3D). This performance may be related to the fact that these conditions $(0 \%)$ are similar to those found in the natural environment of the species, making it the most appropriate for this growth pattern [17]. 

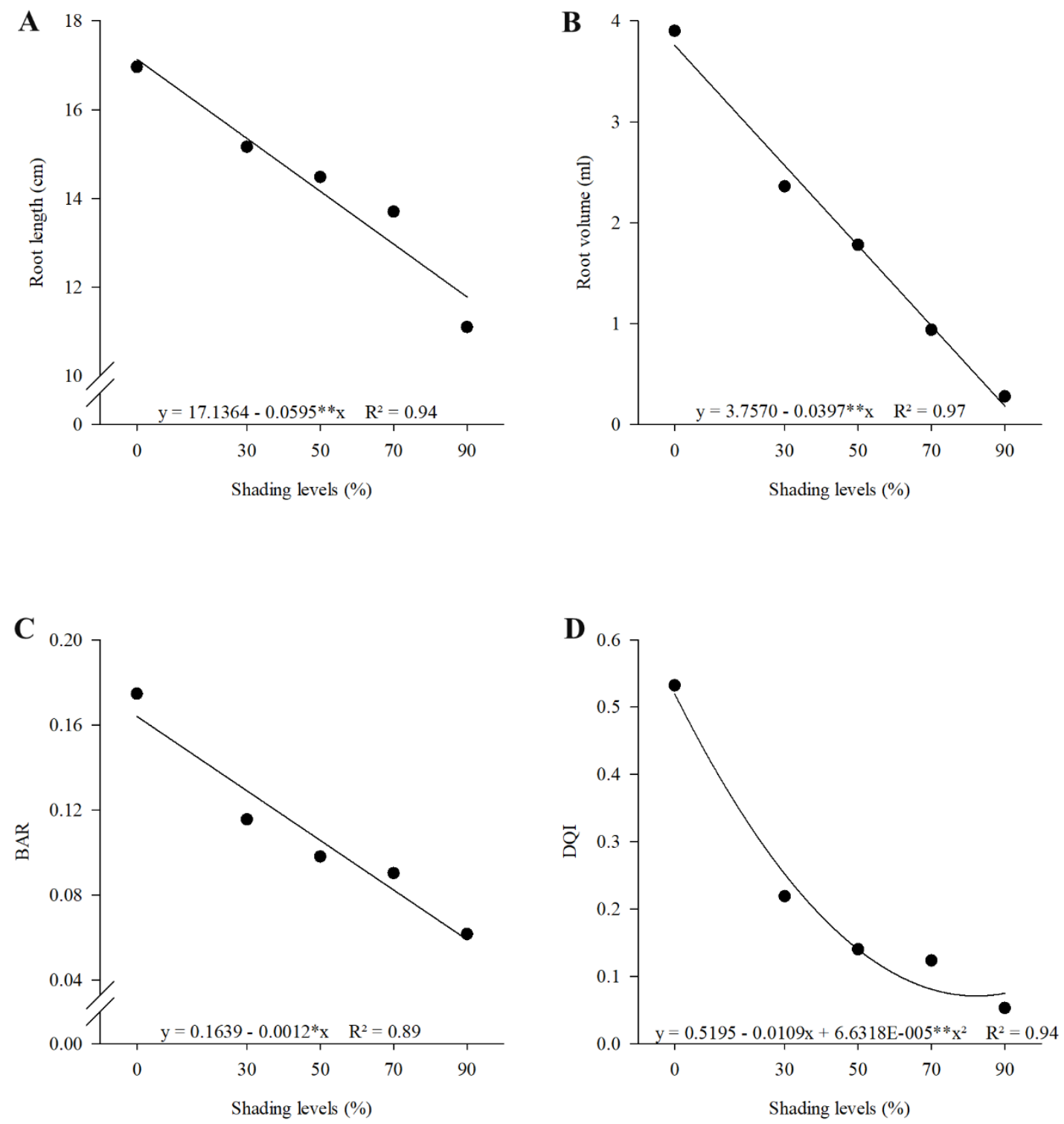

Figure 3: Length of the primary root $(A)$, root system volume $(B)$, root biomass partition $(C)$ and Dickson quality index $(D)$ in plants of silk flower (Calotropis procera) as a function of shading levels.

Observed that there were increases in stomatal conductance up to the shading levels of $24.9 \%$, expressing a value of $0.50 \mathrm{~mol} \mathrm{H}_{2} \mathrm{O} \mathrm{m}^{-2} \mathrm{~s}^{-1}$, reducing the upper levels (Figure 4A). This decrease in stomatal conductance at the highest shading levels was possibly due to a lower $\mathrm{CO}_{2}$ assimilation rate (Figure 4B), caused by stomatal closure and $\mathrm{CO}_{2}$ concentration within the substomatic chamber, impairing activities in the photosynthetic apparatus [18].

The increase in shading provided linear reductions in the $\mathrm{CO}_{2}$ assimilation rate (A) and in the transpiration rate (E), with reductions of 36.8 and $31.7 \%$, respectively (Figures $4 \mathrm{~B}$ and $\mathrm{C}$ ). These decreases are possibly related to the stomatal limitation imposed by these treatments (Figure 4A), because reductions in gs induce a lower entry of $\mathrm{CO}_{2}$ into the mesophyll cells and consequently lower water loss to the environment [19]. The negative effect of shading on these parameters was due to the fact that the luminosity is one of the factors that act most on the stomatal opening and closing mechanism, associated with this in shading conditions, does not occur the complete activation of photosystems, a fact that directly influences the photochemical process of photosynthesis [20].

The internal $\mathrm{CO}_{2}$ concentration (iC) was reduced until a shading of $42.5 \%$, increasing at levels above the above mentioned (Figure 4D). This increase in higher shading levels may be associated 
with a marked reduction in the rate of photosynthesis (Figure 5B), which results in a lower consumption of $\mathrm{CO}_{2}$ during the carboxylation process [19].
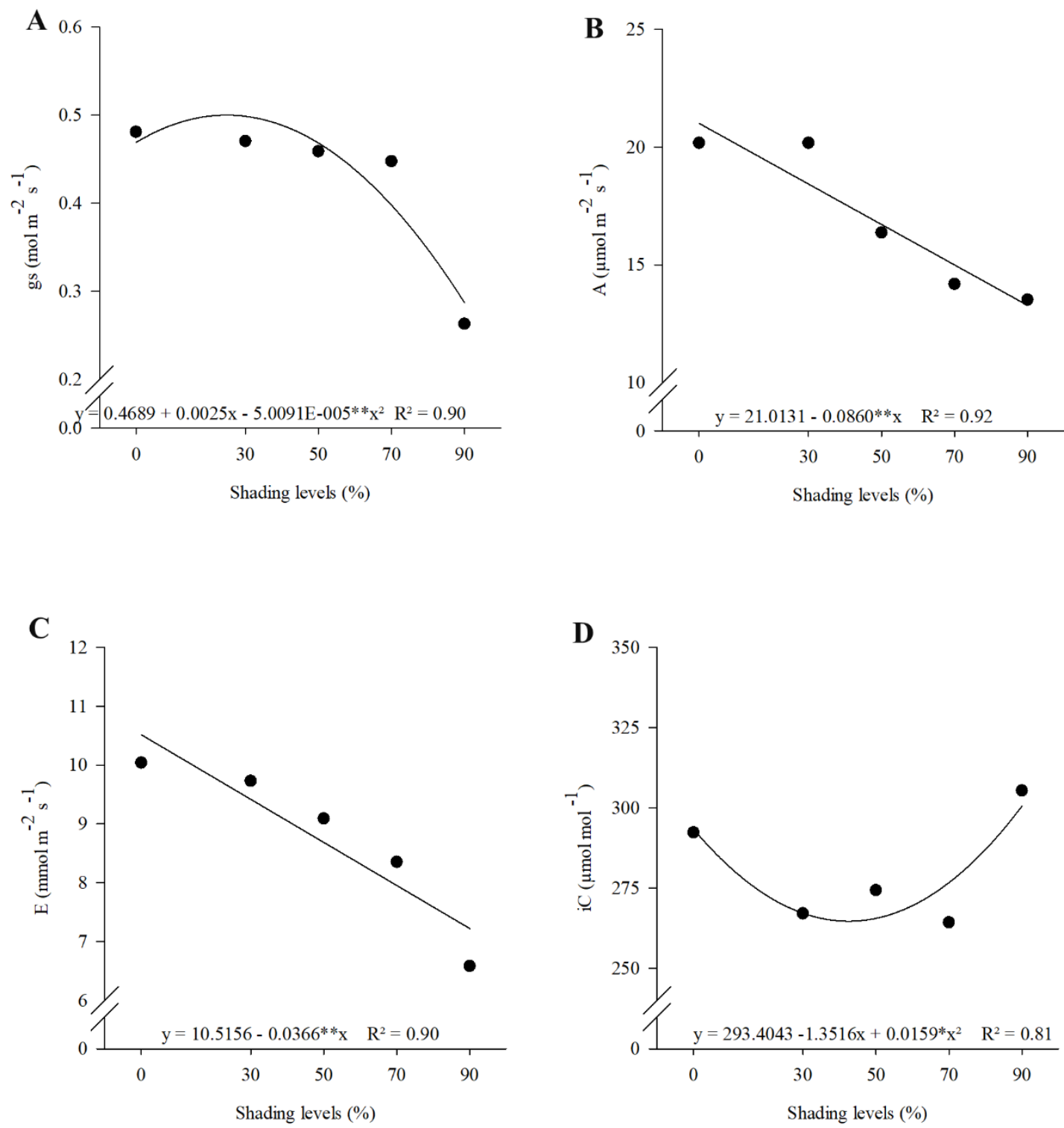

Figure 4: $\mathrm{CO}_{2}$ assimilation rate (A), stomatal conductance (B), transpiration $(C)$ and internal $\mathrm{CO}_{2}$ concentration $(D)$ in plants of silk flower (Calotropis procera) as a function of shading levels.

Water use efficiency (WUE) had the maximum shading efficiency of 25.5\% (Figure 5A). This variable has a close relationship with the net photosynthesis and the transpiration rate. In this sense, reductions in the net assimilation of $\mathrm{CO}_{2}$ implies in a lower loss of water by plants [21].

The instantaneous carboxylation efficiency (iCE) and the leaf temperature (Tleaf) were reduced linearly with the increase of shading levels, being registered decreases of 35.3 and $7.9 \%$, respectively, when comparing between treatments of greater shading $(90 \%)$ with full sun $(0 \%)$ (Figures 5B and $\mathrm{C}$ ). The reduction observed in $\mathrm{A}$, influenced directly in the iCE, since a smaller amount of $\mathrm{CO}_{2}$ is being fixed by Rubisco [22]. This variable is also an indication if non-stomatic factors influenced the photosynthetic rate of the plants [23]. 

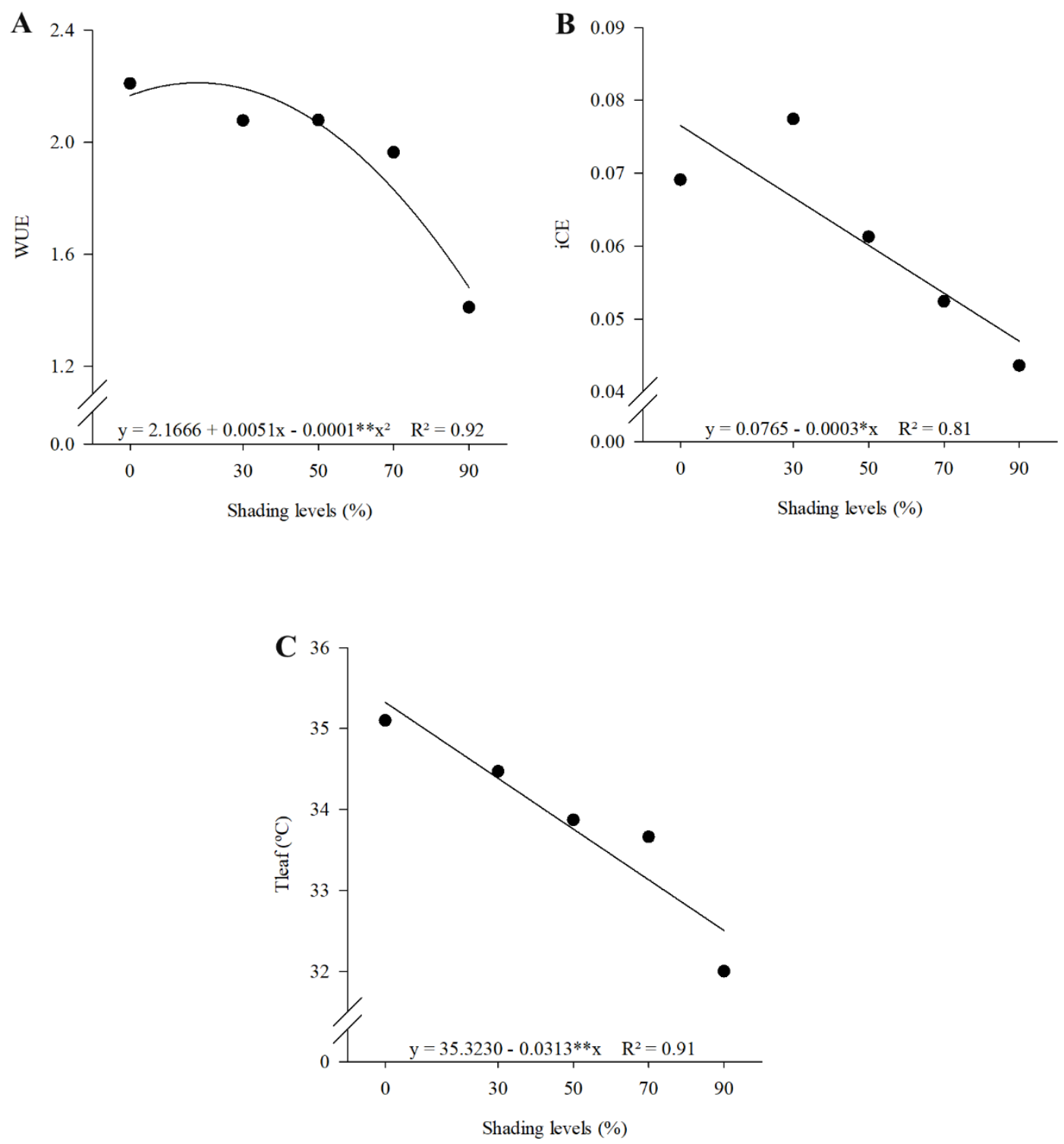

Figure 5: Water use efficiency (A), instantaneous carboxylation efficiency $(B)$ and leaf temperature $(C)$ in plants of silk flower (Calotropis procera) as a function of shading levels.

The chlorophyll a fluorescence parameters, it is noted that the initial fluorescence $\left(\mathrm{F}_{0}\right)$ presented an increasing linear behavior due to the increase in shading levels, with values of 179.98 and 225.02 electrons quantum ${ }^{-1}$ for treatments of $0 \%$ (full sun) and $90 \%$, respectively, with an increase of $25 \%$ (Figure 6A). This increase observed in $\mathrm{F}_{0}$ was possibly due to the fact that silk flower plants, when subjected to shading conditions, had their ability to transfer excitation energy to the PSII reduced [24].

Under the conditions the present study was carried out, silk flower plants presented higher values for maximum $\left(\mathrm{F}_{\mathrm{m}}\right)$ and variable $\left(\mathrm{F}_{\mathrm{v}}\right)$ fluorescence in full sun treatments $(0 \%)$, with values in the order of 855.36 and 672.35 electrons quantum ${ }^{-1}$. However, reductions of 23.5 and $35.7 \%$ were found for these variables, respectively, in the treatments with higher level $(90 \%)$ of shading when compared to the control one (0\%) (Figures 6B and C).

$\mathrm{F}_{\mathrm{m}}$ refers to the condition in which the reaction centers of PSII reached their maximum capacity, i.e., when all the quinone was totally reduced, thus, some plants present increases in $F_{m}$ as a mechanism of acclimatization to shading, aiming at maximizing light absorption [25], a fact that contrasts to the one observed in the present study. $F_{v}$, on the other hand, refers to the potential active energy in PSII, which leads us to deduce that the increasing shading levels induced a low activity of PSII and dissipation of excitation energy as heat [26]. 
Quantum efficiency of PSII $\left(\mathrm{F}_{\mathrm{v}} / \mathrm{F}_{\mathrm{m}}\right)$ and the $\mathrm{F}_{\mathrm{v}} / \mathrm{F}_{0}$ ratio, it is noted that the shading levels influenced negatively, with the best results recorded in plants grown in full sunlight, expressing values in the order of 0.79 and 3.62 electrons quantum ${ }^{-1}$, respectively (Figures $6 \mathrm{D}$ and $\mathrm{E}$ ). The $\mathrm{F}_{\mathrm{v}} / \mathrm{F}_{\mathrm{m}}$ represents the energy conversion efficiency of light in the PSII reaction center, while the $F_{v} / F_{0}$ ratio represents the activity of PSII. In this perspective, leaves of plants developed in full sun have a greater number of components of the photosynthetic apparatus, providing photosynthetic capacity per unit of leaf area [27].
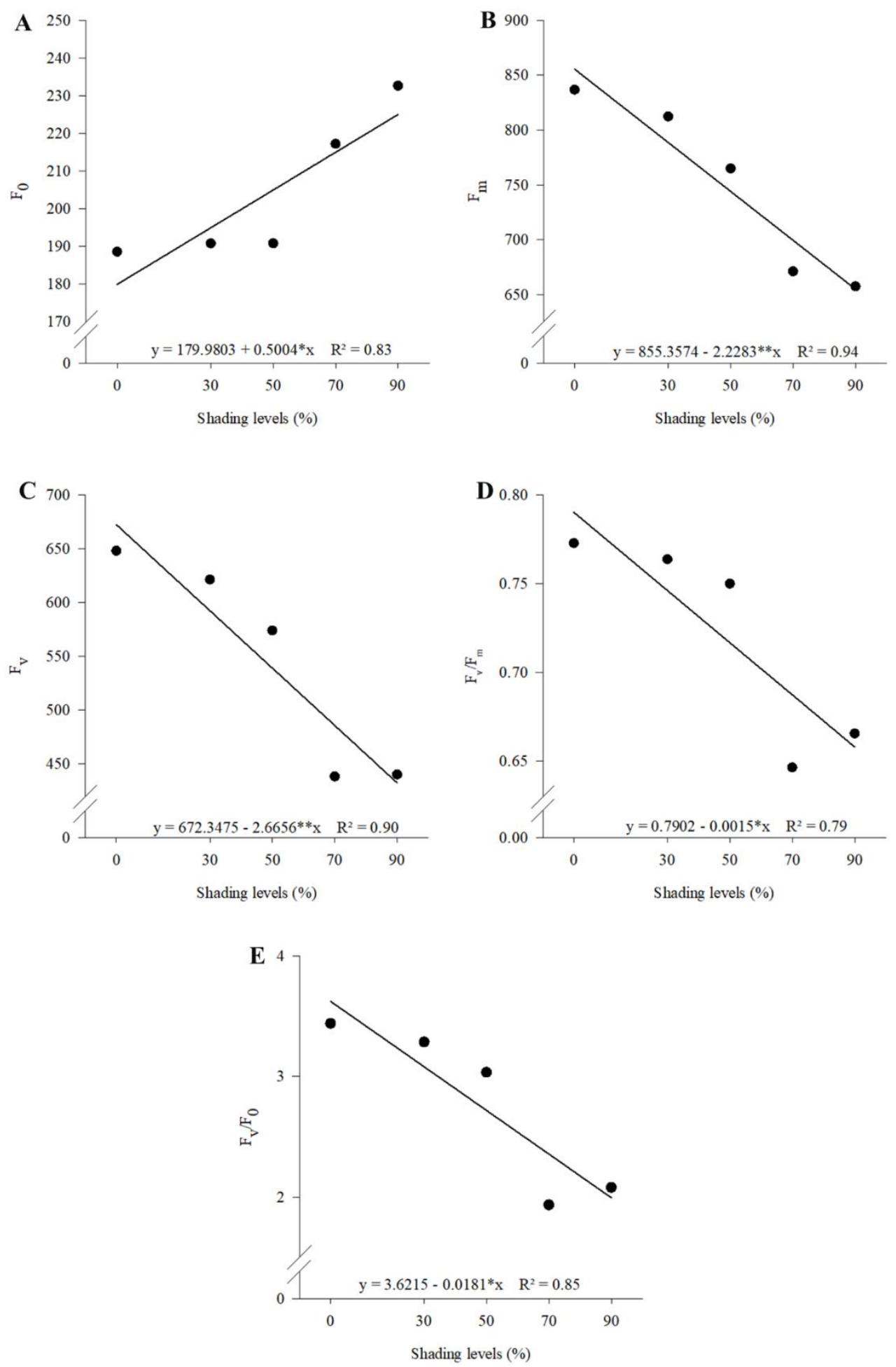

Figure 6: Initial fluorescence $(A)$, maximum fluorescence $(B)$, variable fluorescence $(C)$, maximum quantum yield of PSII $(D)$ and $F_{\vee} / F_{0}$ ratio $(E)$ in plants of silk flower (Calotropis procera) as a function of shading levels. 


\section{CONCLUSION}

Silk flower plants grow best under full sunlight conditions. Shading negatively affects the physiology of silk flower plants inducing plants to etiolation and decrease gas exchange and quantum efficiency.

\section{ACKNOWLEDGMENTS}

This research was financed in part by the Coordination for the Improvement of Higher Education Personnel - Brazil (CAPES) - Finance Code 001.

\section{REFERENCES}

1. Chundattu SJ, Agrawaal VK, Ganesh N. Phytochemical investigation of Calotropis procera. Arab J Chem 2016;9:230-234, doi: 10.1016/j.arabjc.2011.03.011

2. Bezerra Neto F, Silva ML, Lima JSS, Barros Júnior AP, Silva IN, Chaves AP. Productive viability and profitability of carrot-cowpea intercropping using different amounts of Calotropis procera. Rev Caatinga 2019;32:62-71.

3. Belém CS, Souza AM, Lima PR, Carvalho FAL, Queiroz MAA, Costa MM. Digestibility, fermentation and microbiological characteristics of Calotropis procera silage with different quantities of grape pomace. Ciênc Agrotec 2016;40:698-705, doi: 10.1590/1413-70542016406020916

4. Yang L, Wen KS, Ruan X, Zhao YX, Wei F, Wang Q. Response of plant secondary metabolites to environmental factors. Molecules 2018;23:1-26, doi: 10.3390/molecules23040762

5. Felsemburgh CA, Santos KJS, Camargo PB, Carmo JB, Tribuzy ES. Respostas ecofisiológicas de Aniba parviflora ao sombreamento artificial. Pesq Fl Bras 2016;36:201-210, doi: 10.4336/2016.pfb.36.87.964

6. Dutra TRDutra TR, Massad MD, Santana RC. Parâmetros fisiológicos de mudas de copaíba sob diferentes substratos e condições de sombreamento. Ciênc Rural 2012;42:1212-1218, doi: 10.1590/S010384782012005000048

7. Atroch EMAC, Soares AM, Alvarenga AA, Castro EM. Crescimento, teor de clorofilas, distribuição de biomassa e características anatômicas de plantas jovens de Bauhinia forficata Link submetidas à diferentes condiç̃oes de sombreamento. Ciênc Agrotec 2001;25:853-862

8. Lima-Júnior EC, Alvarenga AA, Castro EM, Vieira CV, Oliveira HM. Trocas gasosas, características das folhas e crescimento de plantas jovens de Cupania vernalis Camb. submetidas a diferentes níveis de sombreamento. Ciênc Rural 2005;35:1092-1097, doi: 10.1590/S0103-84782005000500016

9. Dousseau S, Alvarenga AA, Santos MO, Arantes LO. Influência de diferentes condições de sombreamento sobre o crescimento de Tapirira guianensis Alb. Rev Bras Bioc 2007;5:477-479.

10. Albuquerque TCS, Evangelista, TC, Neto AARA. Níveis de sombreamento no crescimento de mudas de castanheira do Brasil. Rev Agro@mbiente 2015;9:440-445, doi: 10.18227/1982-8470ragro.v9i4.3025

11. Benincasa MMP. Análise de crescimento de plantas, noções básicas. Jaboticabal: FUNEP; 2003. 41 p.

12. Dickson A, Leaf AL, Hosner JF. Quality appraisal of white spruce and white pine seedling stock in nurseries. Forest Chron 1960:36:10-13, doi: 10.5558/tfc36010-1

13. Cody R. An Introduction to SAS ${ }^{\circledR}$ University Edition. Cary: SAS Institute; 2015. 49 p.

14. Costa E, Mesquita VAG, Leal PAM, Fernandes CD, Abot AR. Formação de mudas de mamão em ambientes de cultivo protegido em diferentes substratos. Rev Ceres 2010;57:679-685, doi: 10.1590/S0034-737X2010000500018

15. Reis SM, Morandi OS, Oliveira B, Oliveira EA, Valadão MBX, Marimon BS, Marimon Junior BH. Influência do sombreamento no desenvolvimento inicial e eficiência no uso de nutrientes de Dilodendron bipinnatum Radkl (Sapindaceae). Sci Forest 2015;43:581-590.

16. Bento SRSO, Torres SB, Bento DAV, Silva BKA, Dantas FJC, Melo VC. Armazenamento de sementes de flor-de-seda (Calotropis procera (Aiton) W.T. Aiton). Rev Caatinga 2015;28:39-47.

17. Valadão MBX, Marimon Junior BH, Morandi PS, Reis SM, Oliveira B, Oliveira EA, Marimon BS. Initial development and biomass partitioning of Physocalymma scaberrimum Pohl (Lythraceae) under different shading levels. Sci Forest 2014;42:129-139.

18. Larcher W. Ecofisiologia vegetal. São Carlos: RIMA; 2006. 532 p. 
19. Taiz L, Zeiger E, Moller IM, Murphy A. Fisiologia e Desenvolvimento Vegetal. Porto Alegre: Artmed; 2017. $858 \mathrm{p}$.

20. Dalmolin AC, Thomas SEO, Almeida BC, Ortiz, CER. Alterações morfofisiológicas de plantas jovens de Curatella americana L. submetidas ao sombreamento. Rev Bras Bioc 2015;13:41-48.

21. Shimazaki K, Doi M, Assmann SM, Kinoshita T. Light regulation of stomatal movement. Ann RevPlant Biol 2007;58:219-247, doi: 10.1146/annurev.arplant.57.032905.105434

22. Sun Y, Gu L, Dickinson RE, Pallardy SG, Baker J, Cao Y, Damatta FM, Dong X. Asymmetrical effects of mesophyll conductance on fundamental photosynthetic parameters and their relationships estimated from leaf gas exchange measurements. Plant, Cell \& Environm 2014;37:978-994, doi: 10.1111/pce.12213

23. Ferraz RLS, Melo AS, Suassuna JF, Brito MEB, Fernandes PD, Nunes Júnior ES. Trocas gasosas e eficiência fotossintética em ecótipos de feijoeiro cultivados no semiárido. Rev Pesq Trop 2012;42:181188, doi: 10.1590/S1983-40632012000200010

24. Sá FVS, Brito MEB, Silva LA, Moreira RCL, Fernandes PD, Figueiredo LC. Fisiologia da percepção do estresse salino em híbridos de tangerineira - Sunki Comum sob solução hidropônica salinizada. Comunicata Sci 2015;6:463-470, doi: 10.14295/CS.v6i4.1121

25. Reed S, Schnell R, Moore MJ, Dunn C. Chlorophyll $a+b$ content and chlorophyll fluorescence in avocado. J Agric Sci 2012;4:29-36, doi: 10.5539/jas.v4n4p29

26. Sá FVS, Gheyi HR, Lima GS, Paiva EP, Moreira RCL, Silva LA. Water salinity, nitrogen and phosphorus on photochemical efficiency and growth of west indian cherry. Rev Bras Eng Agríc Amb 2018;22:158163, doi: 10.1590/1807-1929/agriambi.v22n3p158-163

27. Quin T, Wu Y, Shen Z, Wu Y, Lu D, He J. Effects of shading on leaf physiology and morphology in the 'Yinhong' grape plants. Rev Bras Frutic 2018;40:1-10, doi: 10.1590/0100-29452018037 